\title{
KEDUDUKAN HUKUM PERUSAHAAN BENTUK USAHA TETAP (PERMANENT ESTABLISHMENT) DALAM DIMENSI HUKUM PENANAMAN MODAL DI INDONESIA
}

Oleh:

\author{
Putu Ratih Prabandari ${ }^{1}$, Ni Ketut Supasti Dharmawan ${ }^{2}$, \\ Desak Putu Dewi Kasih ${ }^{3}$
}

\begin{abstract}
Companies with a permanent establishment is a form of a business carried on in Indonesia, carried out either by an individual or entity whose establishment was not done in Indonesia. The company with a permanent establishment differences with the concept of establishment permitted by the Investment Act. Starting from the concept, which raised the question of how the legal position of the company with a permanent establishment in the perspective of the Investment Law.

The general objective of this study is an attempt to develop jurisprudence in relation to the company's legal position with a permanent establishment under the Investment Law. This normative research method, to examine the books and legal materials related to the issue under study.

Companies with a permanent establishment in Indonesia is foreign investment, it is appropriate for the government is required to provide legal protection to the investors, including protecting the rights and interests of investors in investing in Indonesia. In order for them to get their rights in accordance with the laws mandated, so the investment law are expected to protect the interests of the parties who invest either directly or indirectly involved in Indonesia. Guarantee legal certainty to investors, so the investment is economically capable of generating profits for investors.
\end{abstract}

Keywords: Company With Permanent Establishment, Investment, Rule of Law.

Mahasiswa Magister Ilmu Hukum Universitas Udayana, Denpasar, Bali. Alamat : Jalan Bukit Sari Utara No. 20 Denpasar, e-mail: ratih_praba25@yahoo.com

2 Dosen Pengajar Fakultas Hukum Universitas Udayana Denpasar, alamat di Batubulan Sukawati Gianyar, email : arasswk@yahoo.com

3 Dosen Pengajar Fakultas Hukum Universitas Udayana Denpasar, alamat di Denpasar, e-mail : dewiksh@ymail.com 


\section{PENDAHULUAN}

\subsection{Latar Belakang}

Keterbukaan informasi yang merupakan akibat dari globalisasi ekonomi saat ini membuka peluang untuk menanamkan modal di berbagai negara, hal ini menimbulkan persaingan yang ketat dalam perdagangan dunia. Dikaitkan dengan ini, perusahaan sebagai pelaku utama ekonomi akan berusaha untuk terus meningkatkan efisiensi dan efektifitas bisnisnya dan berusaha mengembangkan usahanya sampai melewati batas yurisdiksi suatu negara. ${ }^{4}$ Untuk menyatukan kepentingan penanam modal dengan penerima modal tidaklah mudah, karena apabila negara penerima modal terlalu ketat dalam menetapkan syarat penanaman modal, bisa saja penanam modal mengurungkan niatkan untuk menanamkan modalnya di negara tersebut. Hal ini terjadi karena di era globasasi, penanam modal dapat dengan leluasa untuk menentukan tempat dalam melakukan usahanya tersebut tidak terlalu dibatasi ruang geraknya. Dimana untuk mengatur jalannya bisnis tersebut, sudah barang tentu memerlukan seperangkat aturan yakni hukum penanaman modal sebagai payung hukumnya.

Aspek hukum penanaman modal menjadi bagian yang sanagt penting dari

4 Hendrik Budi Untung, 2010, Hukum Investasi Indonesia, Sinar Grafika, Jakarta, h. 32 . sistem penanaman modal karena bersifat sangat kompleks sehingga tidak setiap jual beli, sewa menyewa, tukar menukar dan perbuatan lain sekedar menghasilkan keuntungan termasuk kedalam konsep penanaman modal. Dengan kehadiran penanam modal asing ke dalam suatu negara yang berdaulat menimbulkan pendapat dengan argumentasi masing-masing antara lain seperti kehadiran penanam modal asing dapat mengancam industri dalam nengeri sendiri dan mengancam kedaulatan negara, sehingga perencanaan, pelaksanaan serta pengendalian sesuai dengan peraturan hukum penanaman modal. ${ }^{5}$

Untuk menjalankan pengelolaan tersebut, umumnya penanam modal asing menggunakan perusahaan multinasional dimana perusahan-perusahaan bisnis yang besar menyesuaikan struktur organisasinya dalam membagi resiko dan memperoleh keuntungan dari keputusan ekonomi. Suatu induk perusahaan yang hendak menjalankan aktifitas usahanya di negara lain seperti di Indonesia, dapat dilakukan dengan mendirikan suatu perusahaan yang berbadan hukum Indonesia (Perusahaan Terbatas) atau dapat juga tidak melalui suatu perseroan terbatas. Atas pendirian cabang perusahaan atau kantor perwakilan dinegara lain dengan suatu perseroan terbatas, maka status

${ }^{5}$ Putu Sudarma Sumadi, 2008, Pengantar Hukum Investasi, Pustaka Sutra, Bandung, h. 9. 
perpajakannya disamakan dengan wajib pajak badan biasa seperti perusahaan lainnya di Indonesia. Sedangkan apabila kantor perwakilan asing itu tidak berbadan hukum Indonesia, maka akan menimbulkan perusahaan dengan bentuk usaha tetap, yang kewajiban perpajakannya diatur dalam Undang-undang Pajak Penghasilan. Pada prinsipnya setiap penanam modal yang menanamkan modalnya di Indonesia harus membayar pajak sebagaimana diatur dalam peraturan perundang-undangan. Untuk dapat mengoptimalkan penerimaan pajak dari setiap kegiatan ekonomi yang terjadi di suatu negara, maka harus tersedia suatu administrasi perpajakan yang baik di negara tersebut. Administrasi pajak yang baik akan dapat memantau kepatuhan pelaksanaan ketentuan perpajakan dari seluruh wajib pajak (Tax Payers).

Perusahaan dengan bentuk usaha tetap yang dijalankan di Indonesia dilakukan baik oleh orang pribadi maupun badan yang pendiriannya tidak dilakukan di Indonesia, memiliki perbedaan konsep dengan bentuk usaha yang diperkenankan menurut Undangundang Penananaman Modal dalam Pasal 5 ayat (2). Suatu badan usaha yang modalnya dari dalam negeri tidak harus dalam bentuk badan hukum untuk bentuk usahanya, lain halnya dengan penanaman modal asing, pembentuk undang-undang mensyarat-kan badan usahanya harus berbentuk badan hukum Perseoan terbatas (PT), dalam kaitannya dengan eksistensi PT sebagai subyek hukum mandiri. Dari pemaparan latar belakang diatas, dalam tulisan lebih lanjut dibahas mengenai "Kedudukan Hukum Perusahaan "Bentuk Usaha Tetap" (Permanent Establishment) Dalam Dimensi Hukum Penanaman Modal Di Indonesia”.

\subsection{Rumusan Masalah}

Dari uraian diatas, timbul masalah yaitu bagaimana kedudukan hukum perusahaan dengan bentuk usaha tetap dalam perspektif Undang-undang Penanaman Modal?

\subsection{Tujuan Penelitian}

Adapun tujuan penelitian ini adalah sebagai upaya dalam pengembangan ilmu hukum dalam kaitannya mengenai kedudukan hukum perusahaan dengan bentuk usaha tetap dalam perspektif Undangundang Penanaman Modal.

\section{METODE PENELITIAN}

Penelitian dalam rangka penulisan ini dengan menggunakan penelitian yuridis normatif, yakni sumber penelitian ilmiah dari sisi normatif guna menemukan kebenaran yang didasarkan pada logika keilmuan. Dimana berpedoman pada norma hukum yang ada pada peraturan perundangundangan, konvensi internasional, perjanjian internasional dan putusan-putusan 
pengadilan serta dengan studi kepustakaan, yang diperoleh dari bahan-bahan yang terkait dengan persoalan yang dibahas. Dalam metode penelitian ini menggunakan bahanbahan yakni mencakup; pertama, bahan hukum primer yaitu bahan-bahan pustaka tentang pengetahuan bahan ilmiah yang mengandung unsur kebaruan mengenai fakta-fakta yang mengangkut perusahaan dengan bentuk usaha tetap. Bahan hukum sekunder yakni buku serta bahan-bahan hukum terkait dengan masalah yang diteliti; serta bahan hukum tertier dengan kamus Bahasa Indonesia dan kamus hukum.

\section{PEMBAHASAN}

Keberadaan penanam modal asing di suatu negara saat ini masing menjadi salah satu alternatif penting dalam memperoleh dana guna melaksanakan pembangunan ekonomi. Dalam meningkatkan pertumbuhan ekonomi suatu negara, peraturan-peraturan yang berkaitan dengan penanaman modal asing perlu diperhatikan. Selain diatur dalam Undang-undang Penanaman Modal, peraturan yang tidak kalah pentingnya dalam mengatur pemasukan bagi suatu negara adalah peraturan pajak. Di kebanyakan negara, sektor pajak merupakan penyumbang terbesar bagi penerimaan negara. Karena merupakan sektor yang penting,negara mengenakan pajak tidak hanya kepada subyek dalam negeri tetapi juga terhadap orang atau badan usaha selain subyek dalam negeri yangberkaitan dengan negara tersebut. Keterkaitan tersebutt sering kali terhambat oleh peraturan perpajakan masing-masing negara, sehingga menyebabkan terjadinya pengenaan pajak berganda terhadap orang pribadi maupun badan usaha yang sama. Dalam penanaman modal, penanam modal dapat melakukan usahanya dengan bentuk pembiayaan (joint venture).

Dalam bentuk pembiayaan ini, pelaku usaha menjadi wajib pajak dalam negeri walaupun menggunakan perusahaan dengan penanaman modal asing serta berbadan hukum sesuai ketentuan yang berlaku di Indonesia. Selain itu perusahaan dengan modal asing dapat melakukan usahanya menggunakan perusahaan dengan bentuk usaha tetap yang dapam proses pendiriannya tidak berdasarkan ketentuan hukum di Indonesia, sehingga perusahaan dengan bentuk usaha tetap adalah bukan wajib pajak dalam negeri. Terkait dengan pengenaan pajak berganda tersebut, tidak jarang menyebabkan penanam modal mengurungkan niatnya untuk menanamkan modalnya di suatu negara. Selain masalah pengenaan apajk berganda, penyelundupan pajak juga acap kali terjadi terjadi dengan memamnfaatkan celah-celah yang ada untuk tidak membayar pajak di negara sumber penghasilan dengan melakukan tindakan ilegal yaitu meminimalisir beban pajaknya. 
Untuk menghindari hal itu, maka dibentuklah Persetujuan Penghindaran Pajak Berganda (P3B/Tax Treaty). Dalam persetujuan penghindaran pajak berganda ini juga mengatur mengeni definisi dari perusahaan dengan bentuk usaha tetap (permanent establishment) sebagai suatu tempat tertentu dimana seluruh atau sebagian usaha perusahaan (luar negeri) dijalankan. Selain diatur dalam tax treaty, Undang-undang Pajak Penghasilan juga mengatur tentang perusahaan dengan bentuk usaha tetap pada Pasal 2 ayat (5), yang mana mendefinisikan perusahaan dengan bentuk usaha tetap adalah merupakan bentuk usaha yang dijalankan di Indonesia, dilakukan baik oleh orang pribadi maupun badan usaha yang pendiriannya tidak dilakukan di Indonesia. Dengan ketentuan bahwa orang pribadi tersebut hanya berada di Indonesia selama 183 hari dalam jangka 1 tahun. Serta badan usaha yang pendiriannya tidak dilakukan di Indonesia serta tidak berkedudukan di Indonesia dalam menjalankan kegiatan usahanya di Indonesia. Sesuai dengan hal tersebut diatas, perusahaan dengan bentuk usaha tetap ini merupakan suatu tempat usaha yang bersifat permanen dengan fasilitas-fasilitas yang dapat berupa tanah, gedung, maupun alat kelengkapan lain guna menunjang kegiatan usahanya. Perusahaan dengan bentuk usaha tetap ini dapat menjalankan usahanya menggunakan agen atau perantara yang berkedudukan bebas dalam rangka melaksanakan perusahannya sendiri.

Sejalan dengan pengertian dari perusahaan dengan bentuk usaha tetap diatas yang merupakan pelaku usaha, sesuai dengan Undang-undang Anti Monopoli dan Persaingan Usaha Tidak Sehat dalam Pasal 1 angka 5 dan Undang-undang Perlindungan konsumen pada Pasal 1 angka 3 sama -sama menyebutkan pelaku usaha merupakan orang atau badan usaha baik badan usaha tersebut berbadan hukum atau tidak, yang didirikan dan berada di Indonesia serta melakukan kegiatan usaha di bidang ekonomi di wilayah Indonesia, dalam menyelenggarakan kegiatan usahanya tersebut secara sendiri maupun bersama-sama berdasarkan perjanjian. Berdasarkan pengertian pelaku usaha dari kedua undang-undang diatas, maka perusahaan dengan bentuk usaha tetap yang juga merupakan pelaku usaha ini memiliki kriteria yang khusus yaitu:

1. Orang pribadi yang tidak berkedudukan di Indonesia atau berada tidak lebih dari batas waktu yang ditentukan Undangundang pajak penghasilan

2. Badan usaha yang pendirian dan berkedudukan tidak di Indonesia, namun melakukan kegiatan di Indonesia.

3. Adanya tempat usaha yang bersifat permanen untuk menjalankan usahanya. 
4. Adanya ketergantungan dengan perusahaan induk yang berada di luar negeri.

5. Dibatasi oleh time test atau jangka waktu sesuai dengan Tax Treaty dengan negara mitra.

Dengan adanya perusahaan dengan bentuk usaha tetap di Indonesia yang mana merupakan penanaman modal asing, untuk itu sudah semestinya pemerintah wajib memberikan perlindungan hukum terhadap penanam modal termasuk melindungi kepentingan dan hak-hak penanam modal di dalam menanamkan modalnya di Indonesia. Agar mereka mendapatkan hak-haknya sesuai dengan apa yang diamanatkan dalam undang-undang. Maka kepentingan dari para penanam modal baik itu dengan modal dalam negeri maupun luar negeri dapat diakomodir oleh Undang-undang Penanaman Modal, sehingga mampu menarik lebih banyak penanam modal untuk menanamkan modalnya di Indonesia. Karena penanam modal yang datang kesuatu negara, sebelum menanamkan modalnya melakukan penelitian pendahuluan melalui studi kelayakan, baik dari aspek hukum, finansial maupun politik apakah kondusif untuk berbisnis dinegara yang dituju. Hal ini sangat dibutuhkan untuk memprediksi besarnya resiko yang dihadapi. Adanya sifat kehatihatian dari para penanam modal ini dapat dimengerti mengingat modal yang dibawa tidak semata-mata dalam bentuk uang segar saja, tetapi juga berupa aset yang tidak berwujud seperti Hak atas Kekayaan Intelektual ataupun lainnya. Sebagaimana diketahui untuk mendapatkan HKI membtuuthkan biaya yang tidak sedikit, jadi cukup beralasan jika penanam modal asing berharap dalam melakukan usahanya mendapatkan perlindungan hukum di negara tujuan penanam modal menanamkan modalnya.

Dengan adanya kepastian hukum yang diberikan kepada para penanam modal dalam melakukan usahanya ini mampu memberikan jaminan keuntungan secara ekonomis bagi para pihak. Dengan kata lain penanam modal mempunyai kesempatan ekonomi sehingga dapat digunakan untuk mengembangkan usahanya. Selain itu kepatian hukum yang mencerminkan nilai keadilan dan tidak bersifat diskriminatif juga dibutuhkan baik dari aspek substansi hukumnya mulai dari undang-undang hingga putusan pengadilan. Guna menjamin adanya konsistensi dalam pelaksanaan peraturan diperlukan adanya dukungan aparatur hukum yang profesional dan bermoral serta didukung dengan adanya budaya hukum masyarakat. Selain kepastian hukum, stabilitas politik juga mempengaruhi keberlangsungan penanaman modal asing di suatu negara.

Dalam mewujudkan sistem hukum 
yang mampu mendukung iklim penanaman modal diperlukan aturan yang jelas mulai dari ijin usaha sampai dengan biaya-biaya yang harus dikeluarkan untuk mengopersikan perusahaan. Bagi penanam modal dibutuhkannya suatu acuan yang dapat dijadikan tolak ukur atau pegangan dalam melakukan kegiatan usahanya. Sehingga dengan adanya aspek keadilan, seperti para pemodal asing yang menanamkan modalnya di Indonesia diperlakukan sama di depan hukum dan pada birokrasi pemerintahan. Dengan demikian mampu mencegah mekanisme birokrasi yang kadang berbelitbelit $^{6}$ dan lama proses penyelesaiannya.

Dalam memperoleh perlindungan hukum, bagi penanam modal asing yang menjalankan usahanya di Indonesia, diharapkan perusahaan yang dibentuk tersebut dengan bentuk perseroan terbatas yang didasarkan pada aturan hukum Indonesia serta bertempat kedudukan di wilayah Indonesia sesuai dengan Undangundang Penanaman Modal. Dalam undangundang tersebut mewajibkan untuk penanaman modal yang dilakukan oleh penanam modal tersebut dalam bentuk badan hukum. Karena dengan bentuk badan hukum, ketegasan akan status hukumnya menjadi jelas yakni tunduk pada aturan hukum Indonesia.

${ }^{6}$ Sentosa Sembiring, 2007, Hukum Investasi, CV. Nuansa Aulia, Bandung, h. 37-39.
Dari segi perlindungan penanam modal dalam rangka kepastian hukum yang dianut oleh Undang-undang Penanaman Modal, perusahaan dengan bentuk usaha tetap yang dilakukan oleh orang pribadi yang tidak berkedudukan di Indonesia ini kurang mendapatkan perlindungan hukum, karena penanaman modal yang dilakukan tidak dengan badan usaha yang berbentuk PT. Kekosongan norma terjadi dalam Undangundang Penanaman Modal, karena dalam undang-undang tersebut tidak ada satupun yang menyebutkan mengenai perusahaan dengan bentuk usaha tetap dan perusahaan dengan bentuk usaha tetap hanya disebutkan pada Undang-undang Pajak Penghasilan. Maka payung hukum dari perusahaan dengan bentuk usaha tetap hanya dari Undang-undang Pajak Penghasilan saja.

\section{PENUTUP}

\subsection{Simpulan}

Berdasarkan penulisan melalui pendekatan perundang-undangan dalam penulisan ini, dapat ditarik kesimpulan yakni kedudukann hukum perusahaan dengan bentuk usaha tetap dalam dimensi hukum penanaman modal, merupakan norma kosong karena tidak diatur dalam Undangundang Penanaman Modal. Sehingga perusahaan dengan bentuk usaha tetap tidak mendapat perlindungan hukum mengingat perusahaan dengan bentuk usaha tetap tidak 
diatur dalam Undang-undang Penanaman Modal. Hal ini menunjukkan adanya ketidakpastian hukum dari perusahaan dengan bentuk usaha tetap walaupun jelas diatur dalam Undang-undang Pajak Penghasilan disebutkan sebagai wajib pajak.

\subsection{SARAN}

Karena perusahaan dengan bentuk usaha tetap diminati oleh penanam modal asing, hendaknya para pembentuk undangundang membentuk peraturan yang mengatur lebih lanjut tentang perusahaan dengan bentuk usaha tetap agar tidak terjadi kekosongan norma. Hal ini ditujukan untuk perlindungan hukum guna mendapatkan kepastian hukum yang berhubungan dengan stakeholder yakni pihak ketiga yang terkait. Dengan demikian pemerintah mampu melindungi kepentingan dan hak-hak penanam modal dalam menanamkan modalnya di Indonesia.

\section{DAFTAR PUSTAKA}

\section{Buku}

Devano, Sony, dan Siti Kurnia R, 2006, Perpajakan, Konsep, Teori dan Isu, Kencana Prenada Media Group, Jakarta.

Harjono, Dhaniswara K., 2007, Hukum Penanaman Modal, PT. Raja Grafindo Persada, Jakarta.
Hart, H.L.A, 1994, The Concept of Law Second Edition, Oxford University Press, New York.

HS., Salim, dan Budi Sutrisno, 2008, Hukum Investasi di Indonesia, PT. Raja Grafindo Persada, Jakarta.

Ibrahim, Jhony, 2006, Teori dan Metodologi Penelitian Hukum Normatif, Bayu Publishing, Malang.

Panjaitan, Hulman, 2005, Hukum Penanaman Modal Asing, Ind-Hill Co., Jakarta.

Sembiring, Sentosa, 2007, Hukum Investasi, CV. Nuansa Aulia, Bandung.

Setiawan, Agus, dan Basri Musri, 2006, Perpajakan Umum, PT. Raja Grafindo Persada, Jakarta.

Sumadi, Putu Sudarma, 2008, Pengantar Hukum Investasi, Pustaka Sutra, Bandung.

Untung, Hendrik Budi, 2010, Hukum Investasi Indonesia, Sinar Grafika, Jakarta.

Waluyo, 2005, Perpajakan Indonesia, Salemba Empat, Jakarta.

Zakaria, Jaja, 2005, Perlakuan Perpajakan Terhadap Bentuk Usaha Tetap (BUT), PT. Raja Grafindo Persada, Jakarta.

2005, Perjanjian Penghindaran Pajak Berganda Serta Penerapannya di Indonesia, PT. Raja Grafindo Persada, Jakarta.

\section{PeraturanPerundang-Undangan}

Undang-undang No. 25 tahun 2007 tentang Penanaman Modal.

Undang-undang No. 36 tahun 2008 tentang Pajak Penghasilan. 